\title{
REAL BURIALS OR CENOTAPHS? A STUDY OF THE MYSTERI- OUS UNDER-MOUND FUNERARY CONSTRUCTIONS OF THE TRZCINIEC CULTURAL CIRCLE
}

This article presents a recently recognized type of Trzciniec Cultural Circe (TCC) funerary structure, which over the last decade has been excavated in the cemeteries of Bukivna, Nieciecz Wtościańska, and has also been identified during the study of archival material from Komariv. These constructions are characterized by the placement of stones in the corners and along the sides of a rectangular plan. Due to the lack of skeletal remains, these structures are sometimes interpreted as symbolic graves (cenotaphs). Based on multidisciplinary methods, including radiocarbon, geochemical and geological analyzes, excavation, as well as study of archival documentation, the authors can state these features occurred in different enclaves of the TCC and were an important component of the funeral rite during the classical stage of the development of this cultural formation. Their form, structure, location, and inventory also indicate that these unique features probably played an important and universal role in the varied and multidimensional TCC funeral ceremonies.

Keywords: funeral rite, under-barrow architecture, funeral construction, Trzciniec Cultural Circle, barrows.

Introduction. The Middle Bronze Age Trzciniec Cultural Circle (TCC) (Makarowicz 2010a, fig. 1) barrows, which are monuments that form their own landscapes and are usually highly visible in the field, hide various under-mound features, the function of which is not limited to the funeral sphere. Sepulchral structures inside the barrows are frequently discovered in different enclaves of this cultural formation (among others Sulimirski 1968; Berezanskaya 1972; Kempisty 1978; Artemenko 1987; Górski 1996; 2010; Taras, Florek 2003, p. 63-69; Makarowicz 2010a, p. $228-242 ; 2019)$, and in recent years have been more broadly interpreted (e. g. Taras, Florek
2003, p. 63-69; Makarowicz 2010a, p. 382-383; 2019; Górski 2010; Piotrowska 2012; Niculică, Boghian 2015).

In this article, the authors consider a specific type of funeral construction sometimes interpreted as a cenotaph (symbolic grave) in which human remains are typically not documented. These constructions occur mainly in the southeast enclave of the TCC, within the Komarów Culture (KC) territory (Sulimirski 1968; Makarowicz, Lysenko, Kočkin 2013a, 2013b; Makarowicz et al. 2016a; Lysenko et al. 2015). Data from the recent excavation in Bukivna (Makarowicz, Lysenko, Kočkin 2013a; 2013b; 2020; Lysenko et al. 2015), analysis and reinterpretation of archival information from the eponymic cemetery in Komariv (Romaniszyn 2018), and results from research in the South Podlasie of northeast Poland (Kiełbasińska et al. 2012) allow a comprehensive examination of this type of funeral structure. The goal of this article is to address the question of the role these under-barrow features played in ritual activity of the TCC societies. Were they, in fact, cenotaphs or perhaps real burials? Furthermore, the authors will present a discussion of the chronology of these constructions, and their importance and symbolism within TCC communities.

It is worth mentioning that these so-called cenotaphs are difficult to record during excavation. These funerary structures are relatively 'architecturally fragile and slight' and they do not manifest themselves in the field as, for example, wooden, stone-wooden, or stone mortuary houses, which are known from the most important «Trzciniec» cemeteries (e. g. Florek, Taras 2003, p. 63-69; Makarowicz 2010a, p. 282-283; 2019). Therefore, it seems that the frequency of this sepulchral structure is strongly understated 
in the current literature. This article is the first attempt to interpret the described construction, which also reflects the various and complex funeral rites of the TCC societies.

Database presentation. The problem of the discussed feature type in TCC barrows has not been taken into account in the subject literature. The authors focused on specific features that are similar in form and building material, because they duplicate and repeat a particular architectural scheme. This refers specifically to constructions consisting of single stones arranged on a quadrilateral plan. These stones are usually situated in the corners, in the middle of the sides, or along the walls of the constructions, creating unique structures containing a small space inside. Eight features of this type have been documented presently in the TCC, most from well recognized contexts. Four come from Bukivna, upper Dniester river basin, and were registered during excavations by the Polish-Ukrainian archaeological expedition (Makarowicz, Lysenko, Kočkin 2013a; 2013b; (eds.) 2021; Lysenko et al. 2015). Three similar constructions were discovered during research in Komarów prior to World War II in what was then Eastern Galicia (Sulimirski 1936; 1939; 1964; 1968), and one of these features in Nieciecz Włościańska (Southern Podlasie) was explored during recent investment research (Kiełbasińska et al. 2012). Additionally, after analysing plans and descriptions from archival research, it can be concluded that the frequency of the discussed features was likely much higher; however, they have been partially destroyed or inappropriately explored.

Bukivna cemetery. The necropolis in Bukivna is spatially the largest cemetery of the $\mathrm{KC}$ and covers an area of several square kilometres. Together with the neighbouring cemetery in Milovanye, this necropolis consists of a dozen barrow concentrations with a total of over 150 mounds located on exposed landforms and creating both linear and group alignments (Makarowicz et al. 2016a; 2016b; 2016c; 2018; 2019; (eds.) 2021). The cemetery was explored pre-World War II, in 1931 and 1938 (Bryk 1932; Śmiszko 1937; Siwkówna 1938; Rogozińska 1959), and also during the recent Polish-Ukrainian research project from 2010 to 2014 (Makarowicz, Lysenko, Kočkin 2013a; 2013b; 2020; Lysenko et al. 2015) ${ }^{1}$. During the latter, six barrows were excavated, three of which revealed four features that are preliminary interpreted as «cenotaphs».

1. The project was funded by the National Science Centre of Poland, grant no. 2011/03/B/HS3/00839 «Bukivna. An elite Komarów culture cemetery by the Dnister River», which was undertaken from 2011 to 2015 by scholars from Adam Mickiewicz University in Poznań, the National Academy of Sciences of Ukraine in Kiev, and Vasyl Stephanyk Precarpathian University in Ivano-Frankivsk.
Barrow 1/I/2010 - Feature 3. This feature was located in the central-west sector of Barrow $1 / \mathrm{I} / 2010$. It was rectangular in shape with dimensions of $1.7 \times 0.9 \mathrm{~m}$, the contours of which were marked by ten stones arranged in two parallel rows oriented NNW_-SSE (fig. 1). Moreover, one stone was situated to the northeast, which lengthens the potential wall of this feature. In turn, the southwestern corner of this construction was strengthened by two additional stones, which created a kind of «vestibule». The whole construction was situated between 1.43 and $1.61 \mathrm{~m}$ beneath the top of the barrow. Stones used to build this construction were erratic with dimensions of $18-25 \times 15-23 \times 5-10 \mathrm{~cm}$. They were placed directly within a clay layer. Some burnt oak wooden piles were documented to the east and west of the northern part of this construction. Their dimensions were between 0.9 and $0.5 \mathrm{~m}$ in length, 10.0 to $12.0 \mathrm{~cm}$ in width, and 1.5 to $3.0 \mathrm{~cm}$ in thickness. No human bones were found inside the described feature; only archaeological material was present. Three vessels (a completely preserved pot, a vase, and fragments of another pot) were discovered in the northern part of the construction. Another two containers (a bowl and cup) were excavated from the vicinity of the southeast corner. What is more the deposit also included a rhomboidal-head pin, the remains of a bronze pendant, a flint arrowhead, and a sickle, and another three vessels (a vase, bowl and cup) were found $1.5 \mathrm{~m}$ northeast of the described feature (Makarowicz, Lysenko, Kočkin 2013a, p. 160-162; 2013b, p. 104-107; (eds.) 2021; Lysenko 2015, p. 59-63). Geochemical analysis also revealed increased proportions of phosphorus in this area of the feature (Hildebrandt-Radke, Spychalski 2021).

Barrow 7/I/2014 - Feature 6. The feature was located in the southeast sector of Barrow 7/ $\mathrm{I} / 2014$, at a depth of between 1.81 and $1.90 \mathrm{~m}$ from the top of the mound. It was built from six stones arrange in a rectangular plan oriented NE-SW (fig. 2). The size of the stones ranged from $16 \times 10$ to $23 \times 17 \mathrm{~cm}$. The construction dimensions were $1.7 \times 0.7-0.97 \mathrm{~m}$. The fill of the feature did not differ from the surrounding vicinity and no osteological material was documented inside. One vessel (a vase) was found in the northwest part of this construction. In turn, one mug which lay upside down was excavated from the northwest corner. It appears that this vessel «marked» the corner of this structure, and perhaps was used instead of a stone. An additional two vessels (a pot and amphorae, originally one placed within the other) were excavated in the vicinity of the southwest corner stone.

Barrow 7/I/2014 - Feature 7. The discussed structure was documented in the northwest sector of Barrow 7/I/2014, at a depth of 1.75 to $1.81 \mathrm{~m}$ from the top of the mound. This feature, nearly oval in shape, was oriented NW-SE with 


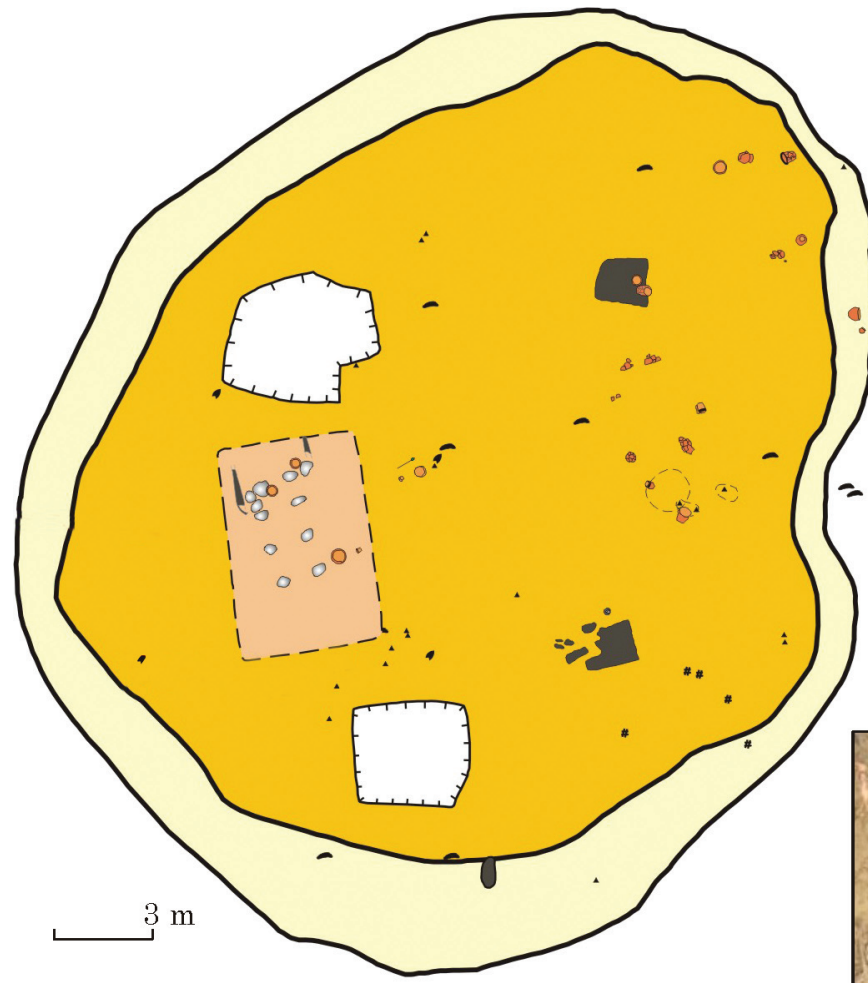

Fig. 1. Feature 3 from Barrow 1/I/2010 in Bukivna

dimensions of $3 \times 1.92 \mathrm{~m}$, and eight stones were situated in a rectangular plan in its interior (fig. 2). The feature fill was "pan-shape» in profile and consist of two layers. The external one consisted of brown soil with admixture of clay and fragmented charcoal in some places. The internal layer (with dimensions of $2.43 \times 1.18 \times 0.25 \mathrm{~m}$ ) consisted of black-brown and dark-grey soil with some tiny pieces of charcoal and a small fraction of clay. The stone construction inside with dimensions of $1.38 \times 0.96 \mathrm{~m}$ was situated parallel to the described layers. Additionally, a small stone was found that extended the northern wall. Another stone was excavated around $0.20 \mathrm{~m}$ to the southwest of the southwestern wall. Four vessels were documented in the Feature 7 context. Three (a vase, cup, and pot) were excavated from the southeast part of the construction. The first was on its side at a distance of $0.5 \mathrm{~m}$ to the southeast of the southeastern cornerstone. Slightly closer (around $0.15 \mathrm{~m}$ ) to the same cornerstone, a cup was found, inside of which was a small pot. Moreover, a bowl lying on its side was deposited in the northwest sector of the described construction. Many charcoal concentrations were observed in the north and northwest parts of this feature. Additionally, several flint tools and small pieces of pottery were documented within the Feature 7 outline, but again no human remains were found.

Barrow 2/I/2010/2012 - Feature 1. Feature 1 from Barrow 2/I/2010/2012 may be another example of the discussed type of funeral structure. This construction was discovered in the central part of the barrow. However, it must be emphasized that the structure was almost completely destroyed by
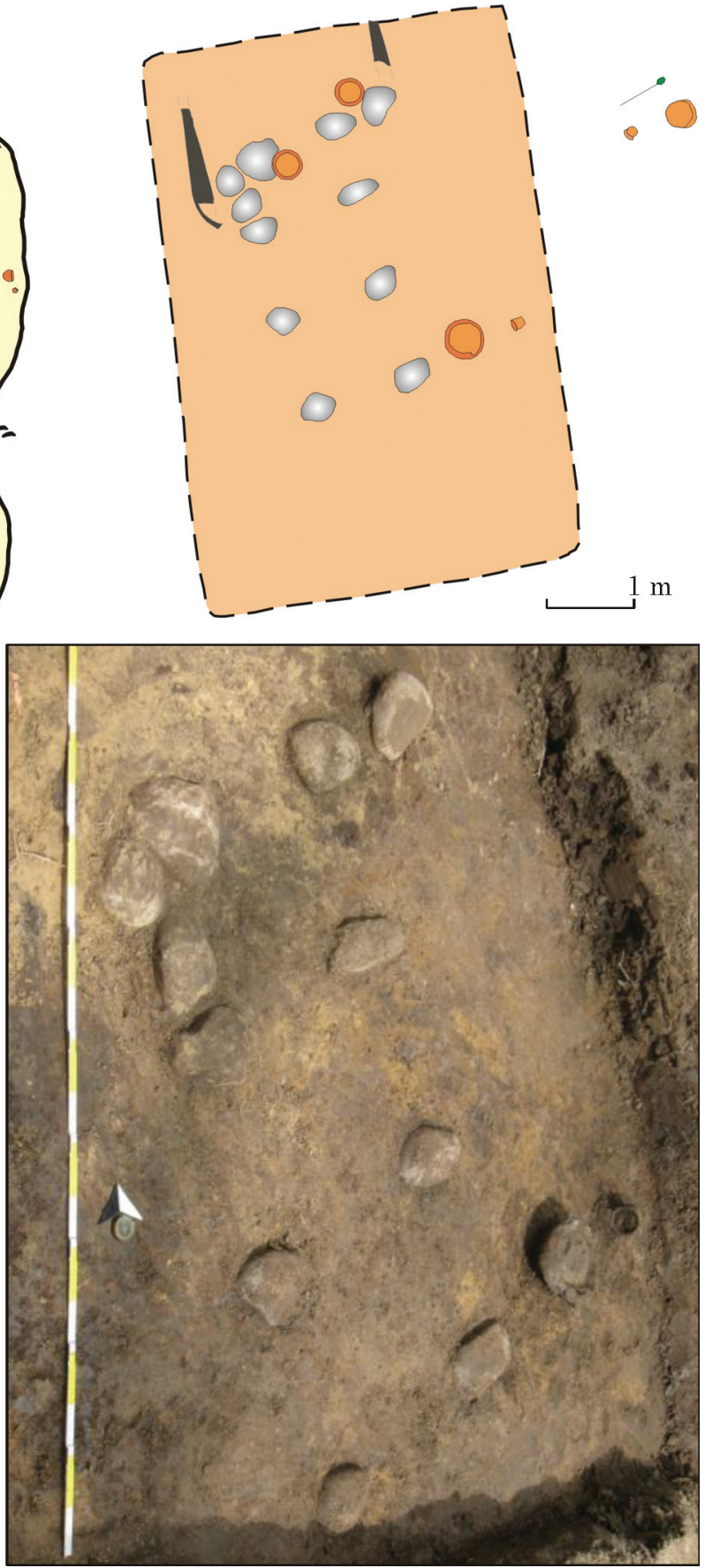

a modern looter's trench, which damaged a substantial part of this mound, especially the central sectors. Due to this, only the eastern section of this construction was preserved (fig. 3). Perhaps two stones with dimensions of $23 \times 20 \times 12$ and $24 \times 15 \times 8 \mathrm{~cm}$ marked the eastern brink of the structure. The distances between the stones that comprise this construction oscillate around $0.7 \mathrm{~m}$, and a fragment of burnt wood with dimensions of $7 \times 5 \times 1 \mathrm{~cm}$, probably the remains of a pile, was observed $0.3 \mathrm{~m}$ to southeast. No osteological material was found in the context of this feature. The equipment of this structure included three vessels. The first (a vase) stood on the southernmost stone. Less than a metre from the vase, the lower part of a S-shaped pot was found. Finally, 

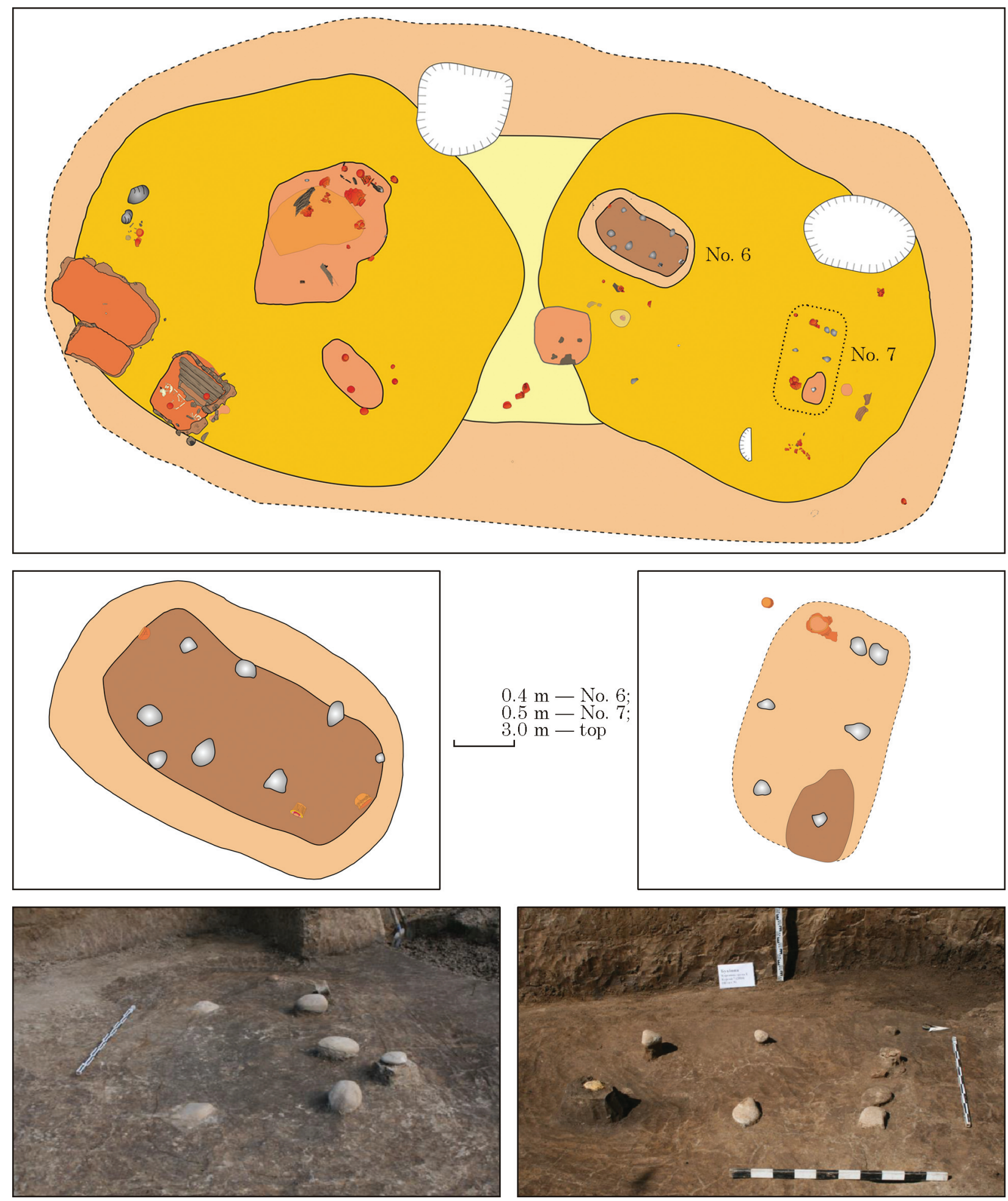

Fig. 2. Features 6 and 7 from double Barrow 6 and 7/I/2010 in Bukivna

a highly fragmented vessel was noticed around $1 \mathrm{~m}$ from the southern edge of the feature. Additionally, the upper part of a nail-headed pin was documented between the mentioned vase and pot. However, it seems like a large part of the feature inventory was stolen by looters.

Komariv cemetery. The cemetery in Komariv (former Komarów) is a part of a larger barrow complex that also includes necropolises in Krylos, Viktoriv, and Medynya. This necropolis is located on the watershed between the Lukva and Limnitsa rivers. As at Bukivna, barrows here create a series of linear and group-linear concentrations, stretching along the highest parts of the terrain (see Makarowicz et al. 2016a; 2016b; 2016c; 2019). The cemetery was explored at the end of $19^{\text {th }}$ century (Ziemięcki 1887); however, the greatest intensification of fieldwork took place from 1934 to 1936 during the wide ranging excavations conducted by Tadeusz Sulimirski and Józef 
Grabowski (Sulimirski 1936; 1939; 1964; 1968, p. 105-119). In total, over 60 barrows were excavated and assigned to the Corded Ware Culture (CWC) and also to the $\mathrm{KC}$.

It appears that three features (two from Barrow 34 and one from Barrow 45) can be considered as the type of under-barrow mortuary architecture discussed in this article. It should also be assumed that pre-war excavation methodologies did not always permit the observation of rectangular features and probably their frequency was higher at this site. Relics of the excavated barrows in the form of "cutting cones» observed during a recent field-walking surveys (Makarowicz 2016a) also suggest that some of the under-barrow architecture located in side sectors of these barrows may have gone undocumented.
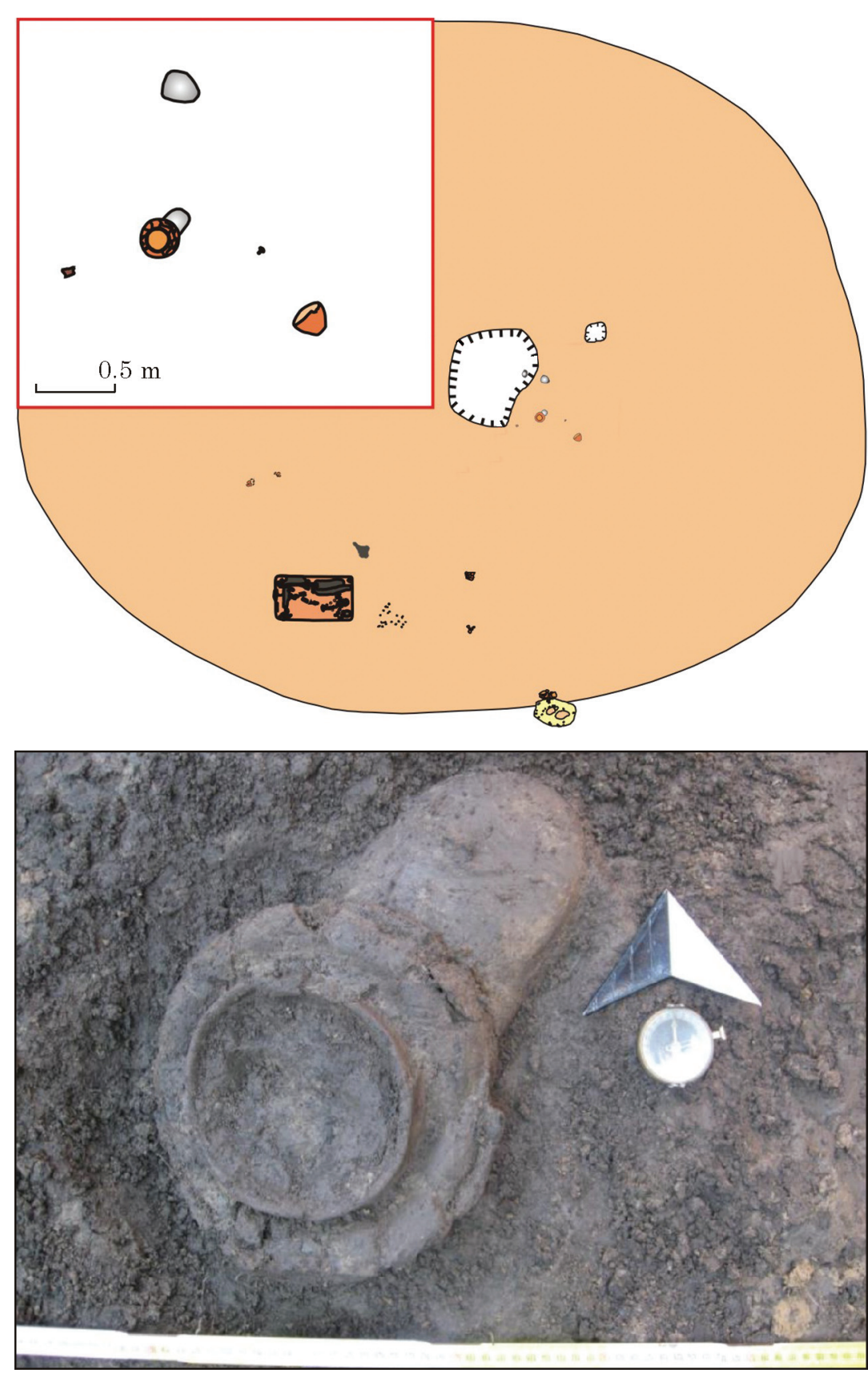

Fig. 3. Feature 1 from Barrow 2/I/2010/2012 in Bukivna
Barrow 34 - Feature A. The central part of the described barrow was destroyed by a second (chronologically subsequent) cremated burial. Around $0.70 \mathrm{~m}$ beneath this structure, the original grave feature was found. It was built from six stones (in the excavators' opinions, they were "halved») with dimensions from 20 to $60 \mathrm{~cm}$ and they marked a rectangular area of $1.5 \mathrm{~m}^{2}$ (fig. 4 : A). This structure was oriented NW-SE and no skeletal material was observed in this context. Three crushed vessels (a bowl, cup, and mug) were deposited in a row along the eastern wall. Another container (possibly a pot with a folded edge) lay around $1 \mathrm{~m}$ to the east of the other vessels. Additionally, a flint arrowhead was found in the northeast corner of the construction. Three pits filled with charcoal were also observed within the feature outline (Sulimirski 1968, p. 111f, plan 19: 2).

Barrow 34 - Feature $B$. In the northeast sector of the same barrow, another feature of the type we are interested in was found around $2 \mathrm{~m}$ to the northwest of Feature A (fig. 4: A). This construction was built from stones arranged in three rows which formed a rectangular shape of $2 \mathrm{~m}^{2}$. The feature recalls examples from barrows at Bukivna; however, after analysing the documentation, it can be concluded that two such structures were built next to each other. A shallow hole with containing three vessels (a cup, mug, and bowl) was observed by the western wall of this feature. As in Feature A, no skeleton traces were found inside Feature B (Sulimirski 1968, p. 111-112; plan 19: 2). It should be mention that analogically to Barrow 7/I/2014 in Bukivna, two features of the discussed type of funeral architecture were documented under the mound of one barrow.

Barrow 45- Feature 1. This feature was located $1.5 \mathrm{~m}$ to northwest of the central point of Barrow 45. It was built from 11 stones arranged in three rows (fig. 4: B). The structure had dimensions of $5.5 \times 3 \mathrm{~m}$ and was oriented SW-NE. In the opinion of the excavators, the described construction likely included more stones that were removed as a result of agricultural activity. When analysing the preserved arrangement of stones, it can be 
Fig. 4. Komariv: A - Features A and B from Barrow 34; B - Feature 1 from the Barrow 45
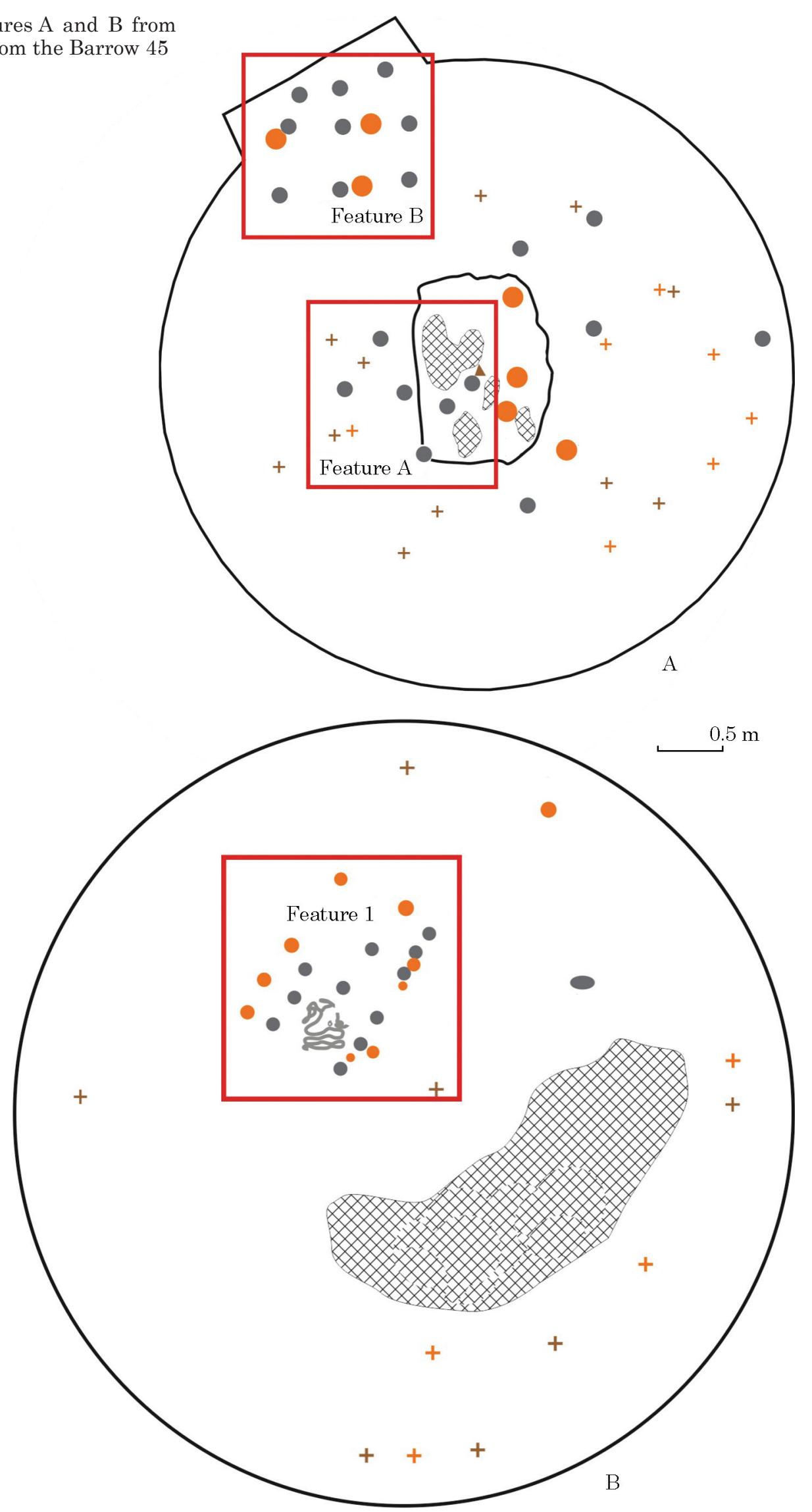

assumed that they originally formed two, adjacent, rectangular structures. Importantly, calcined human bones and charcoal fragments were identified inside the southwest sector of the construction, although osteological material was not observed in the northeast part of this feature. Ten vessels were 
Fig. 5. Grave 2 from the barrow in Nieciecz Włościańska

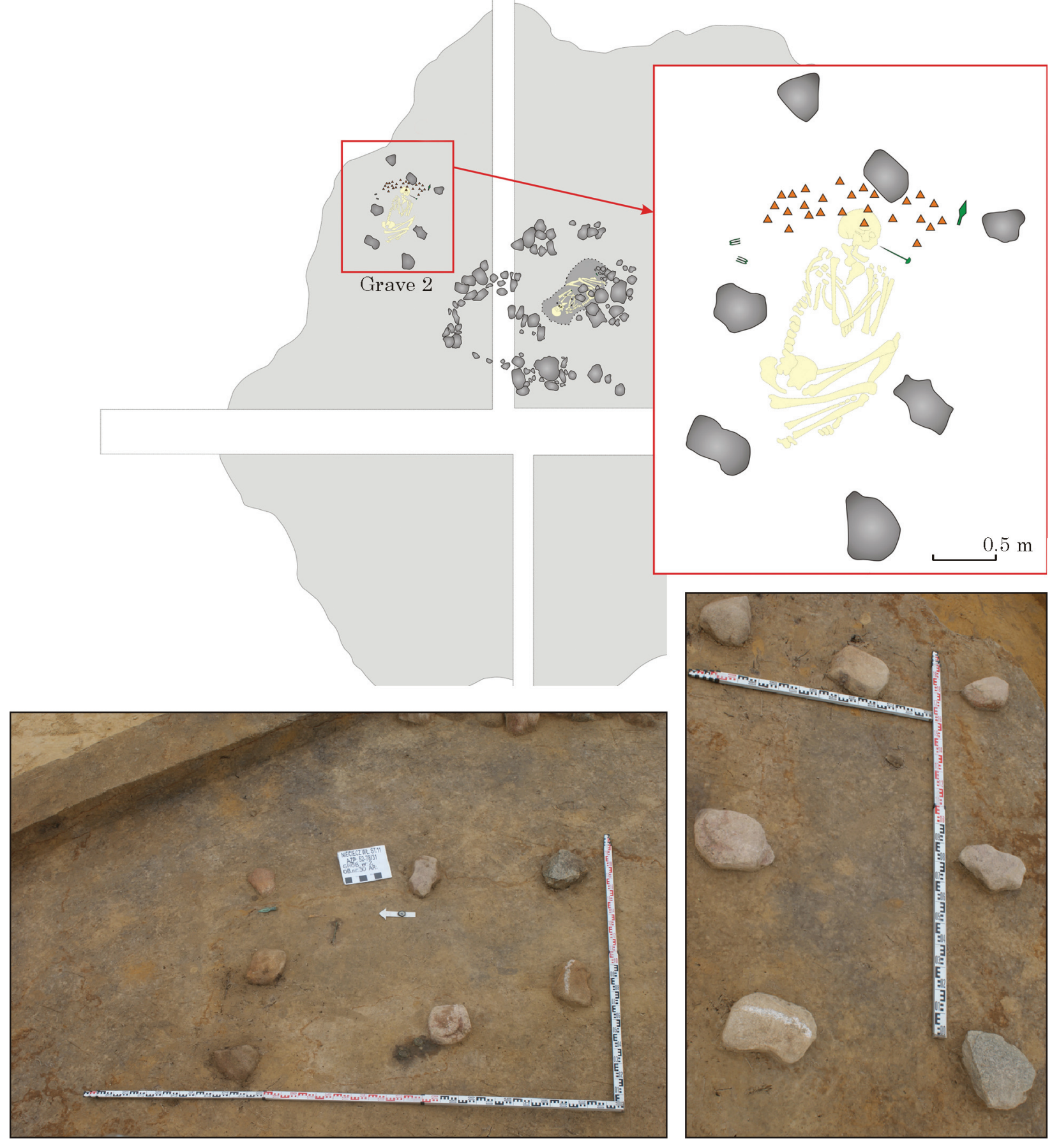

documented within the context of the construction. Similar to the latter examples, all were placed along the walls of the structure. Specifically, four vessels (two pots and two bowls) were deposited next to the northwest wall, one (a bowl) by the north wall, and four (three bowls and a handled mug) by the southeast wall (Sulimirski 1968, p. 114; plan 24: 2).

Nieciecz Włościańska Barrow - Grave 2. The last example of a funerary construction of the type discussed here, is a structure from the barrow in Nieciecz Włościańska (fig. 5). In contrast to the examples presented above, which are located on the belt of the southern highlands, this barrow is located in the northeast area of the
TCC, in South Podlasie. One barrow located on a sandy hill above the Cetynia River Valley was excavated during investment research conducted in 2012 (Kiełbasińska et al. 2012).

In the northeast sector of this barrow a rectangular feature designated «Grave 2» was found. Its contours were formed by six stones arranged in the corners and in the middle of the longer sides of the feature. This structure was oriented NESW. No osteological material was found inside the feature; however, the excavators observed traces of discoloration or "washed hummus", which in their opinion indicated the presence of a deceased whose remains did not preserved due to unfa- 
Calibrated radiocarbon dates from the discussed mortuary features from Nieciecz Włościańska and Bukivna (Oxcal v. 4.4; Bronk Ramsey 2009)

\begin{tabular}{|c|c|c|c|c|c|c|c|}
\hline No. & Barrow & Feature & Conv BP & Cal BC $(68,3 \%)$ & Cal BC (95.4 \%) & Lab no. & Material \\
\hline \multirow[t]{3}{*}{1} & \multicolumn{7}{|c|}{ Nieciecz Włościańska } \\
\hline & 30 & 2 & $3430 \pm 40$ & $\begin{array}{c}1869-1849(9.2) \\
1772-1676(53.6) \\
1654-1641(5.4)\end{array}$ & $\begin{array}{l}1879-1839(13.7) \\
1826-1622(81.8)\end{array}$ & Poz-57704 & Wood \\
\hline & \multicolumn{7}{|l|}{ Bukivna } \\
\hline 2 & 7/I/2014 & 7 & $3425 \pm 30$ & $\begin{array}{c}1863-1855(4.0) \\
1767-1683(59.3) \\
1653-1643(5.0)\end{array}$ & $\begin{array}{c}1873-1845(9.9) \\
1818-1801(2.9) \\
1776-1625(82.7)\end{array}$ & Poz-69118 & Charcoal \\
\hline 3 & $7 / \mathrm{I} / 2014$ & 6 & $3390 \pm 35$ & $\begin{array}{l}1736-1716(14.9) \\
1693-1626(53.4)\end{array}$ & $\begin{array}{c}1867-1851(1.8) \\
1770-1607(89.4) \\
1581-1544(4.3\end{array}$ & Poz-69117 & Charcoal \\
\hline \multirow[t]{2}{*}{4} & \multicolumn{7}{|c|}{ Nieciecz Włościańska } \\
\hline & 30 & 2 & $3340 \pm 35$ & $\begin{array}{c}1669-1656(6.7) \\
1635-1540(61.5)\end{array}$ & $\begin{array}{c}1736-1716(4.9) \\
1692-1518(90.5)\end{array}$ & Poz-57705 & Wood \\
\hline 5 & Bukivna & & & & & & \\
\hline 5 & $1 / \mathrm{I} / 2010$ & 3 & $|3305 \pm 30|$ & $1612-1534(68.3)$ & $\begin{array}{c}1665-1659(0.6) \\
1631-1502(94.9)\end{array}$ & Poz- 88820 & Charcoal \\
\hline
\end{tabular}

OxCal v4.4.2 Bronk Ramsey (2020); r:5 Atmospheric data from Reimer et al. (2020)

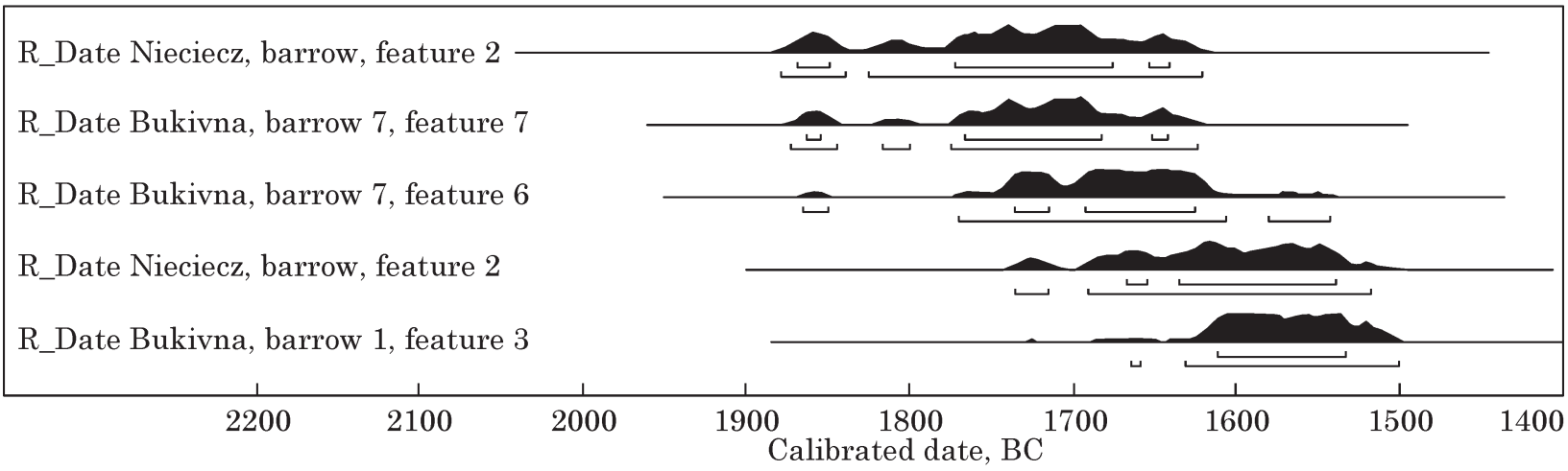

Fig. 6. Radiocarbon dates from Feature 3 - Barrow 1/I/2010, Features 6 and 7 - Barrow 7/I/2014 - Bukivna, Grave 2 - Nieciecz Włościańska

vourable soil conditions. Basing on field observations, they stated that the individual in Grave 2 was buried in a crouched position on his left side with hands folded near his face and the head to the NE. Also, within the context of this feature, a bronze spearhead, nail-head pin, and two spiral bracelets were excavated. Additionally, numerous fragments of a vessel (pot) were documented in the vicinity of the potential deceased's head (Kiełbasińska et al. 2012, p. 5-7).

Chronology. The pottery from the described features generally represents the classic stage of the TCC development, both in the western area (Nieciecz Włościańska), as well as the southeast part occupied by the KC societies (Bukivna). To increase the precision of the absolute chronology of the analysed constructions, five ${ }^{14} \mathrm{C}$ dates from features at both sites were calibrated (table).

After calibration, the chronological ranges suggest that the discussed feature are associated

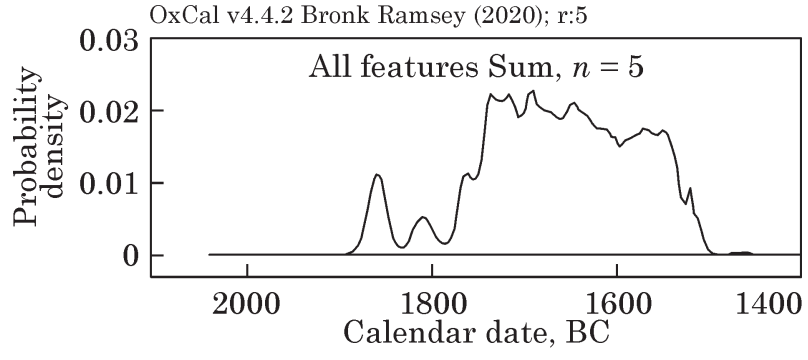

Fig. 7. Sum of probability distribution of radiocarbon dates discussed in the paper

with the earliest, or classic horizon of TCC development in the highland area of its range. The absolute dates point to the $18^{\text {th }}$ to $16^{\text {th }}$ centuries BC as the most probable periods during which this type of under-mound construction was in use (table; fig. 6). Generally, this is also confirmed by the sum of the probability distributions of the obtained ${ }^{14} \mathrm{C}$ values (fig. 7). 
The role of rectangular structures in the funeral practices of TCC societies. Discussion and interpretation. "Trzciniec» funeral rites are characterized by their great variety, complexity, and dynamics of change. Interregional similarities and differences in ritual behaviours are registered in TCC necropolises. Not only burials, but other features with different roles, probably symbolic or ritual, are documented under the mounds of this cultural formation (Górski 2010; Makarowicz 2010, p. 201; Piotrowska 2012, p. 86). These types of funeral structures also include a broad spectrum of constructions that have been registered inside barrows (Makarowicz 2010a, p. 228-242; Górski 2010). Described symbolic structures have various architectonical forms (Florek, Taras 2003, p. 63-69; Górski 2010; 2017; Makarowicz 2010a, p. 228-242; Niculică, Boghian 2015). Specifically, within this wide range of stone and wooden-stone constructions, the following forms can be distinguished: stone boxes (cists), pseudo-cists (stone constructions similar to cists), stone rings, pavements, as well as wooden platforms, coffins, and mortuary houses based on differential architectonical plans (Florek, Taras 2003, p. 63-69; Makarowicz 2010a, p. 231-242; 2019; Niculică, Boghian 2015 , p. 82). It should be mentioned here that parts of the TCC are distinguished by specific funeral architecture. For example, the Biały Potok group (BPG) of the Western Podolia area is characterised by flat inhumated graves tightly cased within stone constructions (Kostrzewski 1928; Romaniszyn, Makarowicz 2018). Also, the area between the Prut and Dnister rivers, covering the current area of Romania and the Republic of Moldova, is rich in stone construction (Shovkoplyas 1952; Dergačev 1986; Boghian, Niculică, Budui 2012; Niculică, Boghian 2015). Nevertheless, the rectangular structures delineated by stones discussed in this article have not received much attention to date in the literature.

The features of interest to us were discovered mostly in the Komarów version of the TCC, in the upper Dniester area. Only one construction was explored in the northern (lowland) extent of the TCC. However, it should be emphasized once again that the features described in this article have architectural layouts that are subtle and difficult to register during excavation. This is confirmed by the documentation record. Among the eight structures known to date, six were explored in the last decade, that is during the period when archaeological technique and tools to record documentation have improved significantly. For example, of the five $\mathrm{KC}$ barrows in Bukivna, the described features were observed under as many as three mounds (Makarowicz et al. (eds.) 2021).

Hitherto, all known rectangular features delineated by stones were discovered beneath mounds, and most were located on the ancient soil level. In addition to these features, structures of dif- fering types were also registered in the same barrows. For example, in Bukivna two separate barrows - Barrow 6/I/2014 measuring $11.5 \times$ $10 \times 1.45 \mathrm{~m}$ (length $\times$ width $\times$ height) and Barrow 7/I/2014 measuring $11.5 \times 10 \times 1.6 \mathrm{~m}$ - were in such close proximity that they created the impression of one longitudinal barrow. Ten features were distinguished during the excavation of these barrows (Makarowicz et al. 2020). In addition to the rectangular constructions described above, clay-wooden mortuary houses (more Makarowicz 2019), ritual deposits of vessels, and fragments of smaller wooden constructions were also recorded. In Barrow 1/I/2010 from this site, five other features were found in addition to a potential cenotaph. There were the remains of two burnt wooden platforms, a stone pavement, and relics of another clay construction (Makarowicz, Lysenko, Kočkin 2013a, p. 160-162; 2013b, p. 104-107; 2020; Lysenko et al. 2015, p. 59-63). In the Nieciecz Włościańska barrow, in addition to Grave 2 discussed above, Grave 1 was also documented. It was a construction built of around 100 irregularly shaped stones located in the central part of the barrow. The diameter of this construction was nearly $5 \mathrm{~m}$ and contained a clearly separated space in which the deceased had been buried (Kiełbasińska et al. 2012, p. 5-7). Undoubtedly, constructions accompanying the discussed features were also registered in Barrows 34 and 45 from Komariv. However, brief reports from this excavation, which for example describe some ritual features as an "area with scattered lumps of charcoal», prevent the exact recognition of these construction types (Sulimirski 1968, p. 114, plan 23).

Another common trait of the discussed features was traces of fire activity in the barrow where they were located. One of the TCC under-mound funeral rites was in situ cremation or burning the grave construction with the deceased inside (Makarowicz 2008; 2010a, p. 243; 2019; Romaniszyn 2015, p. 39; 2018; Górski 2017; see Górski et al. 2017). Following the latest interpretations, cremation within the borders of TCC barrows derived from the post-Globular Amphorae culture tradition or from the Carpathian Basin cultures. It cannot be ruled out that this pattern could also have been connected to the middle Dnieper area, where numerous cases of this type were confirmed. Therefore, it is assumed that the tradition of cremating the deceased inside the under-mound constructions has various and omni-directional origins (more Makarowicz 2010a, p. 384-385). In the context of the features of interest in this paper, the practice of burning has a direct impact on the ability to recognize their function. The activity of ritual fire was one of the reasons that some of the construction elements were completely destroyed. Therefore, it cannot be clearly stated that the stones dug into the ancient surface of the rectangular features discussed here were the only 
components of the funeral construction or whether they served as a base for a larger over-ground structure. At this point it is necessary to mention Feature 3 from Barrow 1/I/2010 in Bukivna where the remains of burnt oak piles were found to the east and west of the extreme vertices of the described feature (Makarowicz, Lysenko, Kočkin 2013b, p. 104-105). Thus, a scenario assuming preserved stones on a rectangular plan were a relic (a foundation?) of a larger construction cannot be ruled out. There are examples of this type of TCC monumental funeral structure from Dwikozy and Dacharzów (Ścibior, Ścibior 1990; Florek, Taras 2003), although in both cases they were significantly larger structures - mortuary houses.

It is also difficult to clearly define the role that these stone-lined rectangular features played in the religious life of the builders. Analogically to other under-mound structures, it can be assumed they perform a ritual and symbolic function. Their morphologic specifications, such as their rectangular form, dimensions, borders outlined by stones, and the accompanying inventory suggests that they were a place where a deceased was buried. However, among the eight such constructions discovered to date, only one contained human remains (Komariv, Barrow 45), while traces of a skeleton on the ancient soil was observed in Nieciecz Włościańska. At this point, we pose the question: are the discussed features real burials or do they represent the practice of erecting symbolic graves, or so-called cenotaphs, by TCC communities? The lack of human remains inside the construction forces us to reflect on whether they were intentionally uninterred by the TCC societies or if this is a result of geochemical processes that took place inside the barrow.

These questions may be answered by the results of geochemical analysis of soil samples from the layers where grave constructions were discovered (Hildebrandt-Radke, Spychalski 2021). They indicate different contents of micro- and macrocomponents in the different layers of the mounds, especially in the funeral features and soil filling the vessels. Lack of preserved bones and wood in the contexts of the features discussed here suggests mineralization of the organic material (Hildebrandt-Radke, Spychalski 2021). Conducted analysis have confirmed that bones are significantly more poorly preserved in acidic soil environments (Karlsberg, Richter 2006, p. 130-131). Indeed, preliminary results ${ }^{1}$ indicate the soil $\mathrm{pH}$ from Bukivna samples are acidic, ranging from 3.18 to 5.11, which would have negatively impacted the preservation of bone in these contexts. Experimental research carried out on the remains of animals in various soil environments (Nicholson

\footnotetext{
1. Authors would like to thank Prof. Iwona HildebrandtRadke (Adam Mickiewicz University) who conducted analysis.
}

1993; 1996) also indicate that a number of other factors, such as the depth of deposited feature, the internal structure of the bone, aeration processes, weathering, and micro-organisms activity are crucial in the preservation of bone. These processes are extremely various and require further studies (more Stiner et al. 1995; Nicholson 1996, p. 523-525, 528).

Fire activity also affects the preservation of human bones inside the barrow constructions. Bones subjected to continuous heating lose their properties and bulk, which is caused by loss of water and organic matter including their main component - collagen (Kalsbeek, Richter 2006, p. 125). Observation of bone cremation indicates that the highest loss of bone weight and organic material occurs in the beginning phase of burning at temperatures of between 200 and $500{ }^{\circ} \mathrm{C}$ (Grupe, Hummel 1991, p. 180; Karlsbeek, Richter 2006, p. 127). The analyse of burnt osteological material from Bukivna revealed that when features containing individuals were burned, the temperature oscillated between 600 and $900{ }^{\circ} \mathrm{C}$, sometimes reaching between 1000 and $1200{ }^{\circ} \mathrm{C}$ (Slobodian, Szczepanek 2021). Moreover, research suggests that burnt bones are more susceptible to decomposition in unfavourable soil environments than non-cremated remains. Based on this information, it cannot be excluded that osteological material was either mineralized or completely destroyed in the discussed features. This is supported by the presence of trace amounts of bone observed in two of the discussed features (Sulimirski 1968, p. 114; Kiełbasińska et al. 2012, p. 56). Nevertheless, the current database does not give unequivocal credibility to this hypothesis, and it is not yet possible to state whether the lack of osteological material within most of the features identified here is due to poor bone preservation or because they were real symbolic burials.

The erection of funeral architecture which secure grave pits or general burial areas are known from the Neolithic period (Krzak 1994). On the basis of TCC customs, this issue has been widely described in literature (Taras 2003; Makarowicz 2010a, p. 228-242, 382-383). The establishment of such constructions was likely connected to funeral behaviours that constituted defence systems, as well as preventive and soothing measures for a community suffering after the death of a member (more Durkheim 1903; Brencz 1987). Such rituals had group-forming, educating, and strengthening functions that maintained a group's cohesion and cultivated mutual ties (Górski 1997; Minta-Tworzowska 2000, p. 48; Kadrow 2006, p. 135). In the TCC case, this is reflected in very complex funerary practises. Based on the rites de passage (rites of passage) model of $\mathrm{A}$. van Gennep (1909), it can be established that funeral constructions were a component of various ritual processes. In the literature it is assumed that one of the stages of funeral rites was to appoint a 
closed sacral area where the deceased was to be buried (Kośko 1991, p. 8). In our opinion, the type of construction discussed here could have played this role due to its architectural form as structures that marked sacral space. Additionally, the registered traces of cremation confirm the symbolic act of «securing» the deceased (Kośko 1991, p. 20-21). This hypothesis is also supported by the presence of funeral goods in potential cenotaphs, which are also commonly deposited in actual graves.

To date, considerations of the occurrence of grave architecture in TCC barrows mostly indicate their genesis during the Neolithic and postNeolithic traditions (Florek, Taras 2003, p. 65; Makarowicz 2010a, p. 383; Niculică, Boghian 2015 , p. 86). The presence of grave constructions is common for Neolithic, Bronze Age, and Halstatt period cultures in Europe in both flat as well as barrow cemeteries (Florek, Taras 2003, p. 65). In the context of the described phenomenon, special attention is paid to the continuity of Final Neolithic (in the form of the Globular Amphorae culture - GAC) and early Bronze Age (in the form of CWC) traditions (Makarowicz 2010a, p. 387). In the first case, similarities in grave construction, mass graves, and the manner of body decomposition reflect potential genetic relationships (Makarowicz 2010b, p. 393). The adaptation of some CWC features can be confirmed by the presence of similar forms of funeral architecture, the erection of barrows, and the remains of sepulchral feasts (Makarowicz 2010b, p. 393).

Finally, it must be emphasized that grave goods always occur in the context of the discussed funeral structures. These include vessels, as well as bronze jewellery and weaponry. Their frequency (from one to 10 vessels, as well as accompanying metal artefacts) suggests that the described features played a significant role in the funeral rites of TCC societies and may indicate a burial. The study of the symbolism of grave goods indicate their importance as a «bridge between the living and dead worlds» (Woźny 2005). Special analysis of vessels from Bukivna barrows has confirmed they contained both food and drink (Czaplińska-Kałużna et al. 2017; CzaplińskaKałużna, Rosiak 2021). This supports the fact that the discussed constructions contained funerary inventories typically included with deceased were part of various TCC culture funeral rites by the classic period of this culture group.

Conclusions. The presented type of underbarrow architecture comprising rectangular constructions outlined with stones and containing burial goods, has only recently been recognized during excavation and archival research. The discovery of these features in different parts of the range of TCC societies suggests that these structures were symbolic and universal for this community. These constructions were erected beneath the mounds and the remains of fire activity in these contexts suggest the practice of in situ cremation. The chronology of these features confirms that they were erected in the classic stage of the TCC development, when restructuring of earlier the CWC cemeteries primarily occurred in the upper Dniester area. Probably this was accompanied by the introduction of a number of new ritual behaviours. These aspects distinguished, in various areas, the activity of the TCC societies from earlier sepulchral habits known from the Late Neolithic and the Early Bronze Age, as well as from those of contemporaneous neighbouring cultures. It can therefore be concluded that the discussed features are symbol of new funeral rite quality and development which brought the TCC community.

The closed, rectangular form of the described features, using clay-stone material (probably also wood) to delineate the sacred area suggests that these structures played the role of burials. At this geochemical and anthropological research stage, it is hard to clearly state whether they are real burials. For example, the lack of human remains in the majority of examples of these features may be intentional if they were meant to be symbolic burials. Nevertheless, chemical analyses may indicate the former presence of human bones or organic material that has not preserved in the archaeological record. Undoubtedly, this aspect must be examined in subsequent, more detailed studies. At the current stage of research, it can be concluded that the structure of these features, as well as their location and rich burial equipment suggests their importance, and perhaps crucial rank in TCC funeral activities. The occurrence of these architectural structures beneath TCC mounds also confirms the complexity and multidimensionality of this community's funeral rites, which is often emphasized in the literature.

\section{ЛITЕРАТУРА}

Артеменко, И. И. 1987. Культуры позднего бронзового века южной полосы лесов Европейской части СССР. В: Бадер, О. Н., Крайнов, Д. А., Косарев, М. Ф. (ред.). Эпоха бронзы лесной полосы СССР. Москва: Наука, с. 106-119.

Березанская, С. С. 1972. Средний период бронзового века в северной Украине. Киев: Наукова думка.

Дергачев, В. А. 1986. Молдавия и соседние территории в эпоху бронзы. Кишинев: Штиинца.

Лисенко, С. Д., Шкляревський, Є. І., Разумов, С. М., Макарович, П. К. 2015. Курганний могильник комарівської культури біля с. Буківна. Археологія, 3, c. $58-78$.

Макаровіч, П., Кочкін, І., Небещаньскі Я., Романішин, Я., Цваліньскі, М., Станюк, Р., Лепьонка, Г., Гільдебрандт-Радке, І., Панахид, Г., Болтрик, Ю., Рудь, В., Ваврусевіч, А., Ткачук, Т., Скшинецкі, Р., Багирич, Ц. 2016. Каталог курганних могильників коларівської культури в басейні Верхнього Дністра (колишне Станіславське воєводство). Познань: Університет ім. Адама Міцкевича.

Шовкопляс, I. Г. 1952. Курганний могильник передскіфрського часу на середньому Дністрі. Археологічні пал'ятки УРСР, 4, с. 5-11. 
Bencz, A. 1987. Polska obrzędowości pogrzebowa jako obrzęd przejścia. Lud, 71, p. 215-229.

Boghian, D., Niculică B., Budui V. The usage of natural resources in protohistory (Aenolithic-Haltsatt) in the North-Eastern Carpathian area. Фортеия: збірник заповідника "Тустань", 2, р. 272-291.

Bronk Ramsey, C. 2009. Bayesian analysis of radiocarbon dates. Radiocarbon, 51, 1, p. 337-360.

Bryk, J. 1932. Tymczasowe sprawozdanie z badań w Bukównie, pow. tłumacki. Sprawozdania Polskiej Akademii Umiejętności, 37, p. 21-22.

Czaplińska-Kałużna, J., Rosiak, A., Grams, J., Chałupka, K., Makarowicz, P., Maniukiewicz, W., Szubiakiewicz, E. 2017. The Studies of Archaeological Pottery with the Use of Selected Analytical Techniques. Critical Reviews in Analytical Chemistry, 47, p. 490-498.

Czaplińska-Kałużna, J., Rosiak, A. 2021. Organic residues on pottery from Bukivna. In: Makarowicz, P., Lysenko, S., Kočkin, I. (eds.). Bukivna. An elite necropolis of the Komarów culture on the Dniester. Archaeologia Bimaris. Poznań: UAM (in print).

Durkheim, E. 1903. Próba określeń zjawisk religijnych. Warszawa: Biblioteka Samokształcenia.

Florek, M., Taras, H. 2003. Dacharzów. Cmentarzysko kultury trzcinieckiej. Lublin: UMCS.

Górski, J. 1996. Uwagi o znaczeniu kurhanów dla społeczności kultury trzcinieckiej z obszarów lessowych Zachodniej Małopolski. In: Chochorowski, J. (ed.). Problemy epoki brazu $i$ wczesnej epoki żelaza $w$ Europie Środkowej. Księga jubileuszowa poświęcona Markowi Gedlowi. Kraków, p. 204-211.

Górski, J. 2007. Chronologia kultury trzcinieckiej na lessach Niecki Nidziańskiej. Kraków: Biblioteka Muzeum Archeologicznego w Krakowie.

Górski, J. 2010. Wpływ transkarpackich kontaktów w początkach epoki brazu na sytuacje kulturowa w dorzeczu górnej Wisły. In: Gancarski, J. (ed.). Transkarpackie kontakty kulturowe w epoce kamienia, brazu $i$ wczesnej epoce żelaza. Krosno, p. 225-248.

Górski, J. 2017. The Trzciniec culture. On the periphery of Bronze Age civilization (1800-1100 BC). In: Urbańczyk, P. (ed.). The Past Societies. Polish lands from the first evidence of human presence to the Early Middle Ages. 3: 2000-500 BC. Warszawa: IAE PAN, p. 87-126.

Górski, J., Makarowicz, P., Wawrusiewicz, A. 2011. Osady i cmentarzyska społeczności trzcinieckiego kregu kulturowego $w$ Polesiu, stanowisko 1, woj. Eydzkie. Łódź: Uniwersytet Łódzki.

Grupe, G., Hummel, S. 2001. Trace element studies on experimentally cremated bone: I. Alteration of the chemical composition at high temperatures. Journal of Archaeological Science, 18, p. 177-186.

Hildebrandt-Radke, I., Spychalski, W. 2021. Bukivna. Lithological and geochemical description of barrow-building sediments in Bukivna. In: Makarowicz, P., Lysenko, S., Kočkin, I. (eds.). Bukivna. An elite necropolis of the Komarów culture on the Dniester. Archaeologia Bimaris. Poznań: UAM (in print).

Kadrow, S. 2006. Późny neolit i wczesna epoka brąu w Jurze Ojcowskiej. In: Lech, J., Partyka, J. (eds.). Jura Ojcowska $w$ pradziejach $i$ poczatkach państwa polskiego. Ojców, p. 459-473.

Karlsberg, N., Richter, J. 2006. Preservation of Burned Bones: An Investigation of the Effects of Temperature and $\mathrm{pH}$ on Hardness. Studies in Conservation, 51, p. 123-138.

Kempisty, A. 1978. Schytek neolitu i poczatek epoki brazu na Wyżynie Małopolskiej w świetle badań nad kopcami. Warszawa: Uniwersytet Warszawski.
Kośko, A. 1991. Ze studiów nad kujawska enklawa naddunajskiej cywilizacji wczesno brazowej. Cmentarzysko grupy Dobre w Bożejowicach, woj. Bydgoszcz, stanowisko 8. Poznań; Inowrocław: UAM.

Kostrzewski, J. 1928. Groby eneolityczne ze szkieletami skurczonymi w Białym Potoku (w pow. Czortkowskim). Przeglad Archeologiczny, 3, p. 9-18.

Krzak, Z. 1994. Megality Europy. Warszawa: PWN.

Makarowicz, P. 2008. Elitarne pochówki z kurhanu komarowskiego w Ivanju na Wołyniu - zarys możliwości interpretacyjnych. In: Czebreszuk, J., Bednarczyk, J., Makarowicz, P. (eds.). Na pograniczu światów. Studia z pradziejów międzymorza battyckopontyjskiego ofiarowane Profesorowi Aleksandrowi Kośko w 60 rocznicę urodzin. Poznań, p. 333-352.

Makarowicz, P. 2010a. Trzciniecki krag kulturowy wspólnota pogranicza Wschodu $i$ Zachodu Europy. Poznań: Wydawnictwo Poznańskie.

Makarowicz, P. 2010b. Geneza pochówków zbiorowych w trzcinieckim kręgu kulturowym. In: Czopek, S., Kadrow, S. (eds.). Mente et rutro. Studia archaeologica Johanni Machnik viro doctissimo octogesimo vita anno ab amicis, collegia et discipulis oblata. Rzeszów, p. 379-398.

Makarowicz, P. 2019. Dom zmarłych z kurhanu 6 w Bukivnej. Z badań nad architektura podkurhanowa w górnodniestrzańskiej enklawie kultury komarowskiej. In: Szmyt, M., Chachlikowski, P., Czebreszuk, J., Ignaczak, M., Makarowicz, P. (eds.). Vir Bimaris. Od kujawskiego matecznika do stepów nadczarnomorskich. Studia $z$ dziejów międzymorza battycko-pontyjskiego ofiarowane Profesorowi Aleksandrowi Kośko. Archaeologia Bimaris, Dyskusje, 5. Poznań: UAM, p. 737754 .

Makarowicz, P., Lysenko, S., Kočkin, I. 2013a. Kurhany z epoki brazu nad górnym Dniestrem - polskoukraińskie projekty badawcze. Folia Praehistorica Posnaniensia, 18, p. 151-176.

Makarowicz, P., Lysenko, S., Kočkin, I. 2013b. Wyniki badań cmentarzyska kultury komarowskiej w Bukiwnej nad górnym Dniestrem w 2010 roku. Materiaty Archeologiczne, 39, p. 101-120.

Makarowicz, P., Kochkin, I., Niebieszczański, J., Romaniszyn, J., Cwaliński, M., Staniuk, R., Lepionka, H., Hildebrandt-Radke, I., Panakhyd, H., Boltryk, Y., Rud, V., Wawrusiewicz, A., Tkachuk, T., Skrzyniecki, R., Bahyrycz, C. 2016a. Catalogue of Komarów Culture Barrow Cemeteries in the Uppe Dniester Drainage Basin (former Stanisławów Province). Archaeologia Bimaris Monographies, 8. Poznań: Wydawnictwo Poznańskie.

Makarowicz, P., Kochkin, I., Niebieszczański, J., Romaniszyn, J., Cwaliński, M., Staniuk, R., Lepionka, H., Hildebrandt-Radke, I., Panakhyd, H., Boltryk, Y., Rud, V., Wawrusiewicz, A., Tkachuk, T., Skrzyniecki, R., Bahyrycz, C. 2016b. Katalog cmentarzysk kurhanowych kultury komarowskiej w dorzeczu górnego Dniestru (dawne województwo stanisławowskie). Poznań: UAM.

Makarowicz, P., Goslar, T., Niebieszczański, J., Cwaliński, M., Kochkin, I., Romaniszyn, J., Lysenko, S., Ważny, T. 2018. Middle Bronze Age societies and barrow line chronology. A case study from the Bukivna «necropolis», Upper Dniester Basin, Ukraine. Journal of Archaeological Science, 95, p. 40-51.

Makarowicz, P., Niebieszczański, J., Cwaliński, M., Romaniszyn, J., Rud, V., Kochkin, I. 2019. Barrows in action. Late Neolithic and Middle Bronze Barrow Landscapes in the Upper Dniester Basin, Ukraine. Prahistorische Zeitschrift, 94, 1, p. 92-115. 
Makarowicz, P., Lysenko, S., Kočkin, I. (eds.). 2021. Bukivna. An elite necropolis of the Komarów culture on the Dniester. Archaeologia Bimaris. Poznań: UAM (in print).

Minta-Tworzowska, D. 2000. Archeologiczne rekonstrukcje świata pradziejowego wobec krytyki postmodernistycznej. In: Tabaczyński, S. (ed.). Kultury archeologiczne, a rzeczywistość dziejowa. Warszawa, p. 185-198.

Nicholson, R. 1991. A Morphological Investigation of Burnt Animal Bone and an Evaluation of its Utility in Archaeology. Journal of Archaeological Science, 20, p. 411-428.

Nicholson, R. 1996. Bone Degradation, Burial Medium and Species Representation Debunking the Myths, an Experiment-based Approach. Journal of Archaeological Science, 23, p. 513-533.

Niculică, B. 2015. Epoca Bronzului in Podişul Sucevei. Suceava: Karl A. Romstofer.

Niculică, B., Boghian, D. 2015. Funerary constructions characteristic to the Komariv (Middle Bronze Age) communities of the Suceava Plateau. In: Kogălniceanu, R., Gligor, R., Curcă, S. (eds.). Homines, Funera, Astra 2. Life beyond death in ancient times. Romanian case studies. Oxford, p. 79-92.

Piotrowska, P. 2012. Obrzędowość funeralna ludności kultury trzcinieckiej na ziemiach polskich. In: Czopek, S. (ed.). Hic mortui vivunt. $Z$ badań nad archeologia funeralna. Colectio Archaeologia Ressoviensis, XX. Rzeszów, p. 85-148.

Rogozińska, R. 1959. Cmentarzysko kultury komarowskiej w Bukównie. Materiaty Archeologiczne, 13, p. $45-50$.

Romaniszyn, J. 2018. Rytuat pogrzebowy społeczności kultury komarowskiej. Manuscript of dissertation. Poznań.

Romaniszyn, J., Makarowicz, P. 2018. The Biały Potok group as an enigmatic problem in the first half of the $2^{\text {nd }}$ millenium BC in West Podolia. Fontes Archaeologici Posnanienses, 54, p. 31-55.

Siwkówna, I. 1938. Tymczasowe wyniki badań terenowych w Bukównej, pow. tłumacki. Z otchłani wieków, 13, p. 67-70

Slobodian, T., Szczepanek, A. 2021. Anthropological analyses. In: Makarowicz, P., Lysenko, S., Kočkin, I. (eds.). An elite necropolis of the Komarów culture on the Dniester. Archaeologia Bimaris. Poznań: UAM (in print).

Stiner, M., Kuhn, L., Weiner, S., Bar-Yosef, O. 1995. Differential Burning, Recrystallization, and Fragmentation of Archaeological Bone. Journal of Archaeological Science, 22, p. 223-237.

Sulimirski, T. 1968. Corded Ware and Globular Amphorae North-East of the Carpathians. London: The Athlone.

Sulimirski, T. 1936. Cmentarzysko kurhanowe w Komarowie koło Halicza i kulturya komarowska. Sprawozdania Polskiej Akademii Umiejętności, 16, 9, p. 273-277.

Sulimirski, T. 1939. Kurhany komarowskie. Złoty Szlak, 4, p. 25-33.

Sulimirski, T. 1964. Barrow-Grave 6 at Komarów. University of London Institute of Archaeology Bulletin, 4, p. 171-188.

Ścibior, J., Ścibior, J. 1990. Obiekt schyłkowej (łódzkiej) fazy kultury trzcinieckiej w Dwikozach, woj. Tarnobrzeg. Sprawozdania Archeologiczne, 41, p. 95124.

Śmiszko, M. 1937. Dziennik badań terenowych (sierpień 1937). Okolice: Kołomyi, Śniatynia i Sokala.
Wykopaliska: Bukówna, pow. Ttumacz (manusscript of fieldwork research diary). Lviv.

van Gennep, A. 1909. Les rites de passage. The American Journal of Sociology, 5, p. 707-709.

Ziemięcki, T. 1887. Sprawozdanie z wycieczki archeologicznej, Kryłos, Wiktorów, Komarów pod Haliczem, Ruda pod Rohatyniem. Zbiór Wiadomości do Antropologii Krajowej, 11, p. 52-75.

\section{REFERENCES}

Artemenko, I. I. 1987. Kultury pozdnego bronzovogo veka iuzhnoi polosy lesov Evropeiskoi chasti SSSR. In: Bader, O. N., Krainov, D. A., Kosarev, M. F. (eds.). Epokha bronzy lesnoi polosy SSSR. Moskva: Nauka, s. 106-119.

Berezanskaia, S. S. 1972. Srednii period bronzovogo veka $v$ severnoi Ukraine. Kiev: Naukova dumka.

Dergachev, V. A. 1986. Moldaviia $i$ sosednie territorii $v$ epokhu bronzy. Kishinev: Shtiintsa.

Lysenko, S. D., Shkliarevskyi, Ye. I., Razumov, S. M., Makarovych, P. K. 2015. Kurhannyi mohylnyk komarivskoi kultury bilia s. Bukivna. Arkheolohiia, 3, s. 58-78.

Makarovich, P., Kochkin, I., Niebieshchanski Ya., Romanishyn, Ya., Tsvalinski, M., Staniuk, R., Lieponka, H., Hildebrandt-Radke, I., Panakhyd, H., Boltryk, Yu., Rud, V., Vavrusievich, A., Tkachuk, T., Skshynietski, R., Bahyrych, Ts. 2016. Kataloh kurhannykh mohylnykiv komarivskoi kultury $v$ baseini Verkhnoho Dnistra (kolyshnie Stanislavske voievodstvo). Poznan: Universytet im. Adama Mitskevycha.

Shovkoplias, I. H. 1952. Kurhannyi mohylnyk peredskifskoho chasu na serednomu Dnistri. Arkheolohichni pam'iatky $U R S R, 4$, s. 5- 11 .

Bencz, A. 1987. Polska obrzędowości pogrzebowa jako obrzęd przejścia. Lud, 71, p. 215-229.

Boghian, D., Niculică B., Budui V. The usage of natural resources in protohistory (Aenolithic-Haltsatt) in the NorthEastern Carpathian area. Fortecja: zbyrnik zapovidnika «Tustan", 2, p. 272-291.

Bronk Ramsey, C. 2009. Bayesian analysis of radiocarbon dates. Radiocarbon, 51, 1, p. 337-360.

Bryk, J. 1932. Tymczasowe sprawozdanie z badań w Bukównie, pow. tłumacki. Sprawozdania Polskiej Akademii Umiejętności, 37, p. 21-22.

Czaplińska-Kałużna, J., Rosiak, A., Grams, J., Chałupka, K., Makarowicz, P., Maniukiewicz, W., Szubiakiewicz, E. 2017. The Studies of Archaeological Pottery with the Use of Selected Analytical Techniques. Critical Reviews in Analytical Chemistry, 47, p. 490-498.

Czaplińska-Kałużna, J., Rosiak, A. 2021. Organic residues on pottery from Bukivna. In: Makarowicz, P., Lysenko, S., Kočkin, I. (eds.). Bukivna. An elite necropolis of the Komarów culture on the Dniester. Archaeologia Bimaris. Poznań: UAM (in print).

Durkheim, E. 1903. Próba określeń zjawisk religijnych. Warszawa: Biblioteka Samokształcenia.

Florek, M., Taras, H. 2003. Dacharzów. Cmentarzysko kultury trzcinieckiej. Lublin: UMCS.

Górski, J. 1996. Uwagi o znaczeniu kurhanów dla społeczności kultury trzcinieckiej z obszarów lessowych Zachodniej Małopolski. In: Chochorowski, J. (ed.). Problemy epoki brazu $i$ wczesnej epoki żelaza $w$ Europie Środkowej. Księa jubileuszowa poświęcona Markowi Gedlowi. Kraków, p. 204-211.

Górski, J. 2007. Chronologia kultury trzcinieckiej na lessach Niecki Nidziańskiej. Kraków: Biblioteka Muzeum Archeologicznego w Krakowie.

Górski, J. 2010. Wpływ transkarpackich kontaktów w początkach epoki brąu na sytuację kulturową w dorzeczu górnej Wisły. In: Gancarski, J. (ed.). Transkarpackie kontakty kulturowe $w$ epoce kamienia, brazu $i$ wczesnej epoce żelaza. Krosno, p. 225-248.

Górski, J. 2017. The Trzciniec culture. On the periphery of Bronze Age civilization (1800-1100 BC). In: Urbańczyk, P. (ed.). The Past Societies. Polish lands from the first evidence of human presence to the Early Middle Ages. 3: 2000-500 BC. Warszawa: IAE PAN, p. 87-126. 
Górski, J., Makarowicz, P., Wawrusiewicz, A. 2017. Osady i cmentarzyska społeczności trzcinieckiego kręu kulturowego $w$ Polesiu, stanowisko 1, woj. Łódzkie. Łódź: Uniwersytet Łódzkiego.

Grupe, G., Hummel, S. 2001. Trace element studies on experimentally cremated bone: I. Alteration of the chemical composition at high temperatures. Journal of Archaeological Science, 18, p. 177-186.

Hildebrandt-Radke, I., Spychalski, W. 2021. Bukivna Lithological and geochemical description of barrow-building sediments in Bukivna. In: Makarowicz, P., Lysenko, S., Kočkin, I. (eds.). An elite necropolis of the Komarów culture on the Dniester. Archaeologia Bimaris. Poznań: UAM (in print).

Kadrow, S. 2006. Późny neolit i wczesna epoka brazu w Jurze Ojcowskiej. In: Lech, J., Partyka, J. (eds.). Jura Ojcowska w pradziejach i poczatkach państwa polskiego. Ojców, p. 459473.

Karlsberg, N., Richter, J. 2006. Preservation of Burned Bones: An Investigation of the Effects of Temperature and $\mathrm{pH}$ on Hardness. Studies in Conservation, 51, p. 123-138.

Kempisty, A. 1978. Schytek neolitu i poczatek epoki brazu na Wyżnie Matopolskiej $w$ świetle badań nad kopcami. Warszawa: Uniwersytet Warszawski.

Kośko, A. 1991. Ze studiów nad kujawska enklawa naddunajskiej cywilizacji wczesno brazowej. Cmentarzysko grupy Dobre w Bożejowicach, woj. Bydgoszcz, stanowisko 8. Poznań Inowrocław: UAM

Kostrzewski, J. 1928. Groby eneolityczne ze szkieletami skurczonymi w Białym Potoku (w pow. Czortkowskim). Przeglad Archeologiczny, 3, p. 9-18.

Krzak, Z. 1994. Megality Europy. Warszawa: PWN

Makarowicz, P. 2008. Elitarne pochówki z kurhanu komarowskiego w Ivanju na Wołyniu - zarys możliwości in terpretacyjnych. In: Czebreszuk, J., Bednarczyk, J., Makarowicz, P. (eds.). Na pograniczu światów. Studia z pradziejów międzymorza battycko-pontyjskiego ofiarowane Profesorowi Aleksandrowi Kośko w 60 rocznice urodzin. Poznań, p. 333352.

Makarowicz, P. 2010a. Trzciniecki krag kulturowy - wspólnota pogranicza Wschodu i Zachodu Europy. Archaeologia Bimaris, Monografie, 3. Poznań: Wydawnictwo Poznańskie.

Makarowicz, P. 2010b. Geneza pochówków zbiorowych w trzcinieckim kregu kulturowym. In: Czopek, S., Kadrow, S. (eds.). Mente et rutro. Studia archaeologica Johanni Machnik viro doctissimo octogesimo vita anno ab amicis, collegia et discipulis oblata. Rzeszów, p. 379-398.

Makarowicz, P. 2019. Dom zmarłych z kurhanu 6 w Bukivnej. Z badań nad architektura podkurhanowa w górnodniestrzańskiej enklawie kultury komarowskiej. In Szmyt, M., Chachlikowski, P., Czebreszuk, J., Ignaczak, M., Makarowicz, P. (eds.). Vir Bimaris. Od kujawskiego matecznika do stepów nadczarnomorskich. Studia z dziejów międzymorza battycko-pontyjskiego ofiarowane Profesorowi Aleksandrowi Kośko. Poznań, p. 737-754.

Makarowicz, P., Lysenko, S., Kočkin, I. 2013a. Kurhany z epoki brazu nad górnym Dniestrem - polsko-ukraińskie projekty badawcze. Folia Praehistorica Posnaniensia, 18, p. 151 176.

Makarowicz, P., Lysenko, S., Kočkin, I. 2013b. Wyniki badań cmentarzyska kultury komarowskiej w Bukiwnej nad górnym Dniestrem w 2010 roku. Materiaty Archeologiczne, 39, p. 101-120.

Makarowicz, P., Kochkin, I., Niebieszczański, J., Romaniszyn, J., Cwaliński, M., Staniuk, R., Lepionka, H., Hildebrandt-Radke, I., Panakhyd, H., Boltryk, Y., Rud, V., Wawrusiewicz, A., Tkachuk, T., Skrzyniecki, R., Bahyrycz, C. 2016a Catalogue of Komarów Culture Barrow Cemeteries in the Uppe Dniester Drainage Basin (former Stanistawów Province). Archaeologia Bimaris Monographies, 8. Poznań: Wydawnictwo Poznańskie.

Makarowicz, P., Kochkin, I., Niebieszczański, J., Romaniszyn, J., Cwaliński, M., Staniuk, R., Lepionka, H., Hildebrandt-Radke, I., Panakhyd, H., Boltryk, Y., Rud, V., Wawrusiewicz, A., Tkachuk, T., Skrzyniecki, R., Bahyrycz, C. 2016b. Katalog cmentarzysk kurhanowych kultury komarowskiej w dorzeczu górnego Dniestru (dawne województwo stanistawowskie). Poznań: UAM.
Makarowicz, P., Goslar, T., Niebieszczański, J., Cwaliński, M., Kochkin, I., Romaniszyn, J., Lysenko, S., Ważny, T. 2018. Middle Bronze Age societies and barrow line chronology. A case study from the Bukivna "necropolis», Upper Dniester Basin, Ukraine. Journal of Archaeological Science, 95, p. $40-51$.

Makarowicz, P., Niebieszczański, J., Cwaliński, M., Romaniszyn, J., Rud, V., Kochkin, I. 2019. Barrows in action. Late Neolithic and Middle Bronze Barrow Landscapes in the Upper Dniester Basin, Ukraine. Prahistorische Zeitschrift, 94, 1, p. $92-115$.

Makarowicz, P., Lysenko, S., Kočkin, I. 2021. An elite necropolis of the Komarów culture on the Dniester. Archaeologia Bimaris. Poznań: UAM (in print).

Minta-Tworzowska, D. 2000. Archeologiczne rekonstrukcje świata pradziejowego wobec krytyki post-modernistycznej. In: Tabaczyński, S. (ed.). Kultury archeologiczne, a rzeczywistość dziejowa. Warszawa, p. 185-198.

Nicholson, R. 1991. A Morphological Investigation of Burnt Animal Bone and an Evaluation of its Utility in Archaeology. Journal of Archaeological Science, 20, p. 411-428.

Nicholson, R. 1996. Bone Degradation, Burial Medium and Species Representation Debunking the Myths, an Experiment-based Approach. Journal of Archaeological Science, 23, p. 513-533.

Niculică, B. 2015. Epoca Bronzului in Podişul Sucevei. Suceava: Karl A. Romstofer.

Niculică, B., Boghian, D. 2015. Funerary constructions characteristic to the Komariv (Middle Bronze Age) communities of the Suceava Plateau. In: Kogălniceanu, R., Gligor, R., Curcă, S. (eds.). Homines, Funera, Astra 2. Life beyond death in ancient times. Romanian case studies. Oxford, p. 7992.

Piotrowska, P. 2012. Obrzędowość funeralna ludności kultury trzcinieckiej na ziemiach polskich. In: Czopek, S. (ed.). Hic mortui vivunt. Z badań nad archeologia funeralna. Colectio Archaeologia Ressoviensis, XX. Rzeszów, p. 85-148.

Rogozińska, R. 1959. Cmentarzysko kultury komarowskiej w Bukównie. Materiały Archeologiczne, 13, p. 45-50.

Romaniszyn, J. 2018. Rytuat pogrzebowy spoteczności kultury komarowskiej. Manuscript of dissertation. Poznań

Romaniszyn, J., Makarowicz, P. 2018. The Biały Potok group as an enigmatic problem in the first half of the $2^{\text {nd }}$ millenium BC in West Podolia. Fontes Archaeologici Posnanienses, 54 , p. $31-55$

Siwkówna, I. 1938. Tymczasowe wyniki badań terenowych w Bukównej, pow. tłumacki. $Z$ otchłani wieków, 13, p. 67-70.

Slobodian, T., Szczepanek, A. 2021. Anthropological analyses. In: Makarowicz, P., Lysenko, S., Kočkin, I. (eds.). An elite necropolis of the Komarów culture on the Dniester. Archaeologia Bimaris. Poznań: UAM (in print)

Stiner, M., Kuhn, L., Weiner, S., Bar-Yosef, O. 1995. Differential Burning, Recrystallization, and Fragmentation of Archaeological Bone. Journal of Archaeological Science, 22, p. 223-237.

Sulimirski, T. 1968. Corded Ware and Globular Amphorae North-East of the Carpathians. London: The Athlone.

Sulimirski, T. 1936. Cmentarzysko kurhanowe w Komarowie koło Halicza i kulturya komarowska. Sprawozdania Polskiej Akademii Umiejętności, 16, 9, p. 273-277.

Sulimirski, T. 1939. Kurhany komarowskie. Złoty Szlak, 4, p. 25-33.

Sulimirski, T. 1964. Barrow-Grave 6 at Komarów. University of London Institute of Archaeology Bulletin, 4, p. 171188.

Ścibior, J., Ścibior, J. 1990. Obiekt schyłkowej (łódzkiej) fazy kultury trzcinieckiej w Dwikozach, woj. Tarnobrzeg. Sprawozdania Archeologiczne, 41, p. 95-124.

Smiszko, M. 1937. Dziennik badań terenowych (sierpien 1937). Okolice: Kotomyi, Śniatynia $i$ Sokala. Wykopaliska: Bukówna, pow. Ttumacz (manusscript of fieldwork research diary). Lviv.

van Gennep, A. 1909. Les rites de passage. The American Journal of Sociology, 5, p. 707-709.

Ziemięcki, T. 1887. Sprawozdanie z wycieczki archeologicznej, Kryłos, Wiktorów, Komarów pod Haliczem, Ruda pod Rohatyniem. Zbiór Wiadomości do Antropologii Krajowej, 11, p. $52-75$. 


\section{J. Romaniszyn, P. Makarowicz}

\section{REAL BURIALS OR CENOTAPHS? A STUDY OF THE MYSTERIOUS UNDER-MOUND FUNERARY CONSTRUCTIONS OF THE TRZCINIEC CULTURAL CIRCLE}

The purpose of this article is to present a complex analysis of recently recognised funeral structures discovered in Trzciniec Cultural Circle barrows. These features are rectangular and stones are typically situated in the corners, in the middle of the sides, or along the walls, creating unique structures with clearly delineated interior spaces. However, the function of these features is not well understood. This feature form is fragile and slight, which makes them difficult to record using traditional excavation methods. The majority of these features have been discovered over the last decade now that new documentation and exploration tools are available to archaeologists. These constructions are only known from barrow cemeteries and the remains of in situ cremation were also documented in their context. Their occurrence confirms the variety and complexity of funeral rites of the Trzciniec Cultural Circle community. To date, eight structures of this type are known. Four (Barrow 1/I/2010 - Feature 3; Barrow 7/ I/2014 - Features 6 and 7; Barrow 2/I/2010/2012 Feature 1) were registered in the Bukivna cemetery during the Polish-Ukrainian expedition realized by scholars from Adam Mickiewicz University in Poznań, the National Academy of Sciences of Ukraine in Kiev, and Vasyl Stephanyk Precarpathian University in Ivano-Frankivsk. The study of archival materials from pre-war excavations conducted by T. Sulimirski and J. Grabowski in Komariv revealed another three features of this type (Barrow $34-$ Features A and B; Barrow 45 - Feature 1). One structure of this type (Grave 2) was also excavated in Nieciecz Włościańska in the northeast enclave of the Trzciniec Cultural Circle during recent investment research.

Due to radiocarbon analysis, the authors have securely established the chronology of these features. The obtained radiocarbon values indicate that these constructions were erected during the classic stage of the Trzciniec Cultural Circle, attributable to the 18 to $16^{\text {th }}$ centuries BC, which was confirmed by archaeological material found within these features.

The discussion of the function and symbolism of these constructions suggest that they could play the role of burials. This is also suggested by geochemical analysis of soil samples from the Bukivna cemetery. However, due to the lack of osteological material in most of these features, this aspect remains shrouded in mystery and requires additional studies. Regardless, the form, location in barrows, and funerary inventory of these features suggest that they played important role in funeral rites of the Trzciniec Cultural Circle society.

Keywords: funeral rite, under-barrow architecture, funeral construction, the Trzciniec Cultural Circle, barrows.

\section{Я. Романішин, П. Макаровіч}

\section{СПРАВЖНІ ПОХОВАННЯ ЧИ КЕ- НОТАФИ? ДОСЛІДЖЕННЯ ТАЕМ- НИЧИХ ПОХОВАЛЬНИХ ПІДКУР- ГАННИХ СПОРУД ТШИНЕЦЬКОГО КУЛЬТУРНОГО КОЛА}

Стаття має на меті представити комплексний аналіз поховальних споруд, виявлених нещодавно у курганах тшинецького культурного кола. Ці об'єкти мають прямокутну фрорму, а камені розташовані зазвичай в кутах, посередині боків або вздовж стін, створюючи унікальні конструкщії з чітко окресленими внутрішніми просторами. Однак фрункція цих об’ектів не зрозуміла до кінця. Малі розміри об'ектів ускладнюють їхню фіксацію із використанням традищійних методів розкопок. Більшість із щих об'єктів було виявлено протягом останнього десятиліття, коли для археологів стали доступні нові методи документащії та інструменти для досліджень. Ці споруди відомі лише з курганних могильників, також у їхньому контексті були задокументовані залишки кремащіï in situ. Їхня поява підтверджуе різноманітність та складність поховальних обрядів жителів тшинецького культурного кола. На сьогодні відомо вісім конструкцій џого типу. Чотири із них (курган 1/I/2010 - об'єкт 3; курган 7/I/2014 - об'єкти 6 і 7; курган 2/I/2010/2012 - об’ект 1) були зафіксовані на могильнику у Буківні під час польсько-української експедиції, у якій брали участь науковщі з Університету ім. А. Міщкевича у Познані, Національної академії наук України в Киеві та Прикарпатського університету ім. В. Стефаника в Івано-Франківську. Вивчення архівних матеріалів розкопок довоєнного часу, проведених Т. Сулімирським та Й. Грабовським у Комарові, дало змогу виявити ще три потенщійні кенотафи (курган 34 - об’екти А та В; курган 45 - об’єкт 1). Одну споруду цього типу (поховання 2) також було розкопано у Nieciecz Włościańska у північно-східному анклаві тшинещького культурного кола під час нещодавніх рятівних досліджень.

Завдяки радіовуглецевому аналізу авторами встановлено хронологію цих об’ектів. Отримані радіовуглецеві дати свідчать про те, що досліджувані об'екти були споруджені під час класичного етапу розвитку тшинецького культурного кола, що відноситься до 18-16 ст. до н. е. Це також підтверджено археологічним матеріалом, знайденим в межах цих об'єктів.

Аналіз фрункщії та символіки џих об'єктів свідчить про те, що вони могли виконувати роль поховань. Про це також свідчить геохімічний аналіз зразків грунту з могильника у Буківні. Однак через брак остеологічного матеріалу для більшості із џих об'єктів, цей аспект залишається овіяним таємницею і вимагає додаткових досліджень. Незважаючи на це, форма, розташування в курганах та поховальний інвентар цих об'єктів свідчать про те, що вони відігравали важливу роль у поховальних обрядах населення тшинецького культурного кола.

Ключові слова: похоронна обрядовість, підкурганна архітектура, тшинецьке культурне коло, кургани.

Отрилано 28.09.2020

МАКАРОВІЧ Пшемислав, професор, Університет імені Адама Міцкевича у м. Познань, Польща.

MAKAROWICZ Przemysław, Professor, Adam Mickiewicz University in Poznań, Poland.

ORCID: 0000-0003-4452-7704, e-mail: przemom@amu.edu.pl.

РОМАНІШИН Ян, PhD, Університет імені Адама Міцкевича у м. Познань, Польща.

ROMANISZYN Jan, PhD, Adam Mickiewicz University in Poznan, Poland.

ORCID: 0000-0002-0562-7414, e-mail: janrom89@wp.pl. 